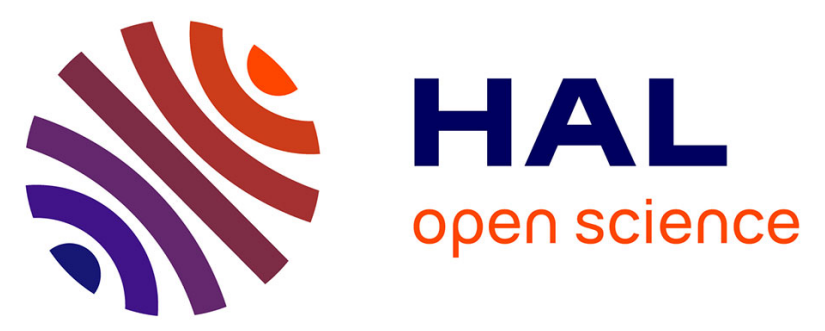

\title{
Downscaling scenarios of future land use and land cover changes using a participatory approach: an application to mountain risk assessment in the Pyrenees (France)
}

Thomas Houet, Marine Gremont, Laure Vacquié, Yann Forget, Apolline Marriotti, Anne Puissant, Séverine Bernardie, Yannick Thiery, Rosalie Vandromme, Gilles Grandjean

\section{To cite this version:}

Thomas Houet, Marine Gremont, Laure Vacquié, Yann Forget, Apolline Marriotti, et al.. Downscaling scenarios of future land use and land cover changes using a participatory approach: an application to mountain risk assessment in the Pyrenees (France). Regional Environmental Change, 2017, 17 (8), pp.2293-2307. 10.1007/s10113-017-1171-z . hal-01631770

\author{
HAL Id: hal-01631770 \\ https://hal.science/hal-01631770
}

Submitted on 9 Nov 2017

HAL is a multi-disciplinary open access archive for the deposit and dissemination of scientific research documents, whether they are published or not. The documents may come from teaching and research institutions in France or abroad, or from public or private research centers.
L'archive ouverte pluridisciplinaire HAL, est destinée au dépôt et à la diffusion de documents scientifiques de niveau recherche, publiés ou non, émanant des établissements d'enseignement et de recherche français ou étrangers, des laboratoires publics ou privés. 
1 Downscaling scenarios of future land use and land cover changes using a participatory approach: an application to mountain risk assessment in the Pyrenees (France)

Thomas Houet ${ }^{1,2, *}$, Marine Grémont ${ }^{3}$, Laure Vacquié ${ }^{2}$, Yann Forget ${ }^{2,4}$, Apolline Marriotti ${ }^{5}$, Anne Puissant ${ }^{6}$, Séverine Bernardie ${ }^{5}$, Yannick Thiery ${ }^{5}$, Rosalie Vandromme ${ }^{5}$, Gilles Grandjean ${ }^{5}$

1 - CNRS, Research laboratory on Littoral, Environment, Geomatic and Remote Sensing (LETG) UMR 6554 / Université Rennes 2, Place du Recteur Henri Le Moal, 35043 Rennes Cedex

2 - CNRS Research laboratory on Environmental Geography UMR 5602 / Université Toulouse Jean-Jaurès, 5 allées Antonio Machado, 31058 Toulouse Cedex

3 - BRGM Unité Nouvelles ressources en eau et économie, 1034 rue de Pinville, 34000 Montpellier, France

4 - Université Libre de Bruxelles, Spatial Epidemiology Lab., CP160/12, 50 avenue F. D. Roosevelt, 1050 Bruxelles, Belgium

5 - BRGM Unité Risque des Instabilités Gravitaires et Erosion des versants, 3 Avenue Claude Guillemin - BP 36009 - 45060 Orléans Cedex 2

6 - CNRS, Research Laboratory on Image, Urban and Environment (LIVE) UMR 7362 CNRS / Université Strasbourg, 3 rue de l'Argonne, F-67000 Strasbourg

* Corresponding Author: thomas.houet@univ-rennes2.fr

\section{Abstract (199 words)}

Better understanding the pathways through which future socio-economic changes might influence land use and land cover changes (LULCC) is a crucial step in accurately assessing the resilience of societies to mountain hazards. Participatory foresight involving local stakeholders may help building fine-scale LULCC scenarios that are consistent with the likely evolution of mountain communities. This paper develops a methodology that combines participatory approaches in downscaling socioeconomic scenarios with LULCC modelling to assess future changes in mountain hazards, applied to a case study located in the French Pyrenees. Four spatially-explicit local scenarios are built each including a narrative, two future land cover maps up to 2040 and 2100, and a set of quantified LULCC. Scenarios are then used to identify areas likely to encounter land cover changes (deforestation, reforestation and encroachment) prone to affect gravitational hazards. In order to demonstrate their interest for decision-making, future land cover maps are used as input to a landslide hazard assessment model. Results highlight that reforestation will continue to be a major trend in all scenarios and confirm that the approach improves the accuracy of landslide hazard computations. This validates the interest of developing fine-scale LULCC models that account for the local knowledge of stakeholders.

\section{Manuscript word count:}

Manuscript:

Figures (4):

Table (1):

\section{7 words}

7007 words

1200 words

300 words

Keywords: Land use and land cover changes; Modelling; Future; Narratives; Stakeholders 


\section{Introduction}

European mountains have experienced substantial transformations in the last century and are expected to face major modifications over the next decades due to both climatic and socio-economic changes. Climate change will affect snow cover, agricultural practices and forest ecosystems (Olesen et al. 2002; Rousselot et al. 2012). These changes will lead to shifts in mountain vegetation that are likely to alter slope stability and to impact natural processes controlled by hydro-meteorological triggers (Katz et al. 1992; Kohler et al. 2014; Borsdorf et al. 2015). Meanwhile, socio-economic transformations will influence human activities, which will not only reshape mountain landscapes but also modify the exposure of societies to mountain hazards (e.g. floods, landslides, avalanches, mudflows, rock falls) (Fuchs et al. 2015b; Papthoma-Köhle et al. 2011). Thus, climatic and socio-economic changes will influence future land use and land cover changes (LULCC), which in turn, will affect both the occurrence of natural hazards and the vulnerability of the built environment to hydro-meteorological risks.

Historically, the main land change trajectory in European mountains has been reforestation due to either de-intensification of agriculture or abandonment of agricultural (pastoral and arable) lands (Kozak et al. 2010; Fuchs et al. 2015a, 2015b; Houet et al. 2015). Most of European mountains and the Pyrenees in particular, where this study takes place, are subject to reforestation owing to the steady decline of population in the region (Galop et al. 2011). Most European spatially-explicit scenariobased studies converge to the same result and expect reforestation to continue into the future (e.g. Verburg et al. 2010; Stürck et al. 2015a, 2015b; Vacquié et al. 2015; Price et al. 2015). Spontaneous reforestation has opposite effects on socio-ecological systems. On the one hand, reforestation may help to reduce gravitational risks by providing new natural protections (e.g. standing trees) and enhancing slope stability (Brang et al. 2001; Thomas and Pollen-Bankhead 2010; Genet et al. 2010; Forbes and Broadhead 2013; Kokutse et al. 2016; Moos et al. 2016). On the other hand, it may decrease the attractiveness of mountains to tourists as it modifies the emblematic character and aesthetics of mountain areas (Gibon et al. 2010; Rey Benayas et al. 2007).

Better accounting for future LULCC is crucial to accurately assess the sustainability of mountain economies and the resilience of societies to mountain risks (Promper et al. 2014). Unfortunately, current practices fall short in this domain. In France, for instance, land management strategies accounting for risk exposure consider only known past hazards and current LULC. They fail to consider the potential feedbacks of future LULCC on the vulnerability of territories to natural hazards. However, considering multi-hazard assessments together with past, current, and future LULCC would contribute to identifying areas that are particularly likely to be threatened by future mountain hazards, and thereby, help design proactive adaptation strategies (IPCC 2012). 
Any attempt to assess future LULCC requires characterizing future socio-economic conditions since they are a significant driver of LULCC and serve as inputs to LULCC models. Because they represent a set of potential future states of the world, scenarios are particularly convenient to explore the uncertainties associated with future socio-economic changes. Scenarios are coherent, internally consistent, and plausible descriptions of the pathways in which driving forces (e.g. technological change, energy costs or climate policies) may influence future developments (Carter et al. 2001; van Vuuren et al. 2014). Depending on their design and development process, scenarios can be classified in many categories (e.g. deterministic versus probabilistic, forecasting versus backcasting, exploratory versus normative) (Carter et al. 2001; van Vuuren et al. 2014). Changes in driving forces may be simulated using numerical methods, such as Monte Carlo simulations (e.g. Graveline et al. 2012). However, such approaches tend to neglect extreme values that would result from breakdowns and structural changes in the economy (Graveline et al. 2014; Rinaudo et al. 2013). Participatory narrative methods involving local stakeholders allow avoiding this shortcoming while ensuring that scenarios are consistent with the local knowledge of stakeholders (Graveline et al. 2014; Malek and Boerboom 2015; Voinov and Bousquet 2010).

Many socio-economic scenarios have been constructed at national and international scales (Bourgau et al. 2008; EEA 2007; Carter et al. 2000; Vert and Portet 2010; Vert et al. 2013; Pérez-Soba et al. 2015; Verkerk et al. 2016). Downscaling these scenarios so that they provide useful inputs to local LULCC models requires analyzing local economic drivers (e.g. employment) and social dynamics (e.g. attractiveness of mountain areas). Some studies have undertaken this exercise with the IPCC special report emission scenarios for Europe (e.g. Rounsevell et al. 2006; EEA 2007; Verburg et al. 2010; Verburg et al. 2013). Based on interpretations of the narratives, quantitative data are derived (from other sectorial models or projections) to define model parameters (e.g. land demand, suitability of areas for specific LULCC transitions - see Stürck et al. 2015b for instance) that simulate quantitative scenarios with a spatial resolution varying from $1 \mathrm{~km}^{2}$ (e.g. Verburg et al. 2010) to few hundred meters (e.g. Price et al. 2015). Nevertheless, their resolution is not appropriate for gravitational hazards that require finer scales of analysis to account for hydro-meteorological triggers and the landscape configuration influencing biogeochemical fluxes. High resolution LULCC simulations based on scenarios (e.g. $10 \times 10$ m pixels or vector-based objects - see for instance Houet et al. 2010, 2014, 2015) are particularly valuable in assessing possible local environmental impacts of future LULCC but show limitations when distant futures or normative visions are considered, for at least two reasons.

First, classical LULCC models struggle to translate narratives into quantitative input data (van Vliet et al. 2010). This is accentuated by the time horizon considered since, the longer it is, the more global drivers have to be accounted for in a telecoupled world (Liu et al. 2013). No conventional approach exists and multiple methods can be used (Mallampalli et al. 2016). Some authors use statistical or 
probabilistic tools to assess the relative and/or respective weights of scenarios' variables (Kok 2009; van Vliet et al. 2010) and then use these weights to parameterize the models. Others use intermediate sectorial models (Stürck et al. 2015b) or expert knowledge to define future land demands (Vacquié et al. 2015).

Second, models using past land cover maps for initialization or calibration (Mas et al. 2014; Houet et al. 2016a) assume stationarity of the system (Kolb et al. 2013). No change of the LULCC drivers may occur in the future, and the simulated outcomes inevitably rely on trend scenarios (Houet 2015). Thus, they are not appropriate to represent non-stationary LULCC affected by regime shifts (Müller et al. 2014). Better suited fine-scale LULCC models should meet three criteria.

(i) They would have to be able to mimic observed LULCC in terms of dynamics (i.e. rates, locations and processes) and to account for interactions between LULCC, which remains challenging (Verburg et al. 2016). For example, mountain land cover trends such as encroachment or reforestation may lead to land use changes (abandonment) of summer agropastoral lands. Inversely, land use changes such as the conversion of forests into new silvicultural lands may induce new land cover dynamics. In most LULCC models, land uses and land covers are grouped together and not modelled separately to integrate such interactions.

(ii) They would also have to be able to take trends and disruptions in scenario storylines into account (i.e. regime shifts and new types of LULCC). Therefore, they have to exhibit both path-dependent (Brown et al. 2005) and non-path dependent properties (Houet et al. 2016a).

(iii) They should provide outcomes that are consistent (in terms of temporal and spatial resolutions) with the knowledge of stakeholders and the requirements of hazard assessment models (e.g. resolution or land cover classes).

Although these criteria place more constraints on the modelling, approaches coupling participation and models such as the Storyline And Simulation (SAS) framework, which consists of elaborating qualitative narratives that are then simulated using adapted LULCC models (Alcamo 2008), can help address this shortcoming.

This paper investigates the contribution of coupling participatory approaches in downscaling socioeconomic prospective scenarios with spatially-explicit LULCC modelling to assess future changes in landslide hazards in the French Pyrenees. Section 2 details the case study and the methodology developed. Section 3 presents the narratives produced and validated by stakeholders and compares the LULCC outcomes of the FORESCEM (FOREcasting SCEnarios for Mountains) model. Future possible landscape changes (reforestation and deforestation) are assessed in a spatially explicit manner and used as inputs to the ALICE (Assessment of Landslides Induced by Climatic Events) model to 
evaluate their potential impacts on landslides. In section 4 , the method is discussed. Section 5 concludes on the interest of the participatory approach and the LULCC model to produce fine-scale spatially explicit scenarios useful to risk assessment.

\section{Material and methods}

\subsection{Study site and observed trajectories}

The study site is located in the French Pyrenees (centered on $0^{\circ} 06^{\prime} 50^{\prime \prime} \mathrm{W}-42^{\circ} 53^{\prime} 27^{\prime \prime} \mathrm{N}$ ) and covers about $70 \mathrm{~km}^{2}$ in the municipal area of Cauterets. The elevation ranges from $800 \mathrm{~m}$ to $2700 \mathrm{~m}$ a.s.l. (Fig. 1a). Land use and land cover maps are derived from multisource GIS data (National Forest Inventory, landscape maps of the Pyrenees National Park) and historical maps based on photointerpretations of aerial photographs.

In 2010, the landscape is composed of grassland and shrubs in the uplands, urban and cultivated areas in the valley bottom, forests and mineral surfaces on the steepest slopes, and a few water bodies (Fig. 1c). It has experienced strong LULCC since the late 1950s (Fig. 1b). Urban areas have increased to the detriment of cultivation. The areas covered by deciduous and mixed coniferous and deciduous forests have largely increased while the extent of open forests has slightly declined. The analysis of gains and losses of land covers shows clear encroachment and reforestation trajectories. Natural grasslands of the uplands have significantly decreased and been converted into shrublands and open forests, while some shrublands have been converted into open forests and large areas of open forests turned into dense forests (Fig 1d).

\section{Figure 1-Approximately here}

Over the last 60 years, socioeconomic development has been based on tourism activities with historic hydrothermal spas and a newly developed ski resort in the late 1970s. Moreover, the municipality has been part of the Pyrenees National Park since its creation in the late 1960s. These socio-economic drivers favored urban development in the bottom part of the valley. Unlike most Pyrenean valleys, Cauterets has kept a stable population since the 1970s with about 1100 permanent inhabitants, although the population of farmers and loggers has significantly decreased (French Institute of Statistics). Pastoral activity is still important in summer, welcoming herds from the outer valleys to the administratively defined uplands called 'estives' (Fig. 1e). The size of sheep herds has decreased slightly since the 1980s while cow and horse herds have remained stable (French General Agricultural Census). Land use practices (e.g. the presence of permanent shepherds) have changed, inducing a decrease in pastoral pressure. Some of the estives, such as the Viscos and Col de Riou areas (Fig 1e), are nearly abandoned nowadays. Forests are under-utilized because of the low profitability of forestry. Finally, Cauterets is of particular interest because it is subject to multiple natural hazards. A major rotational landslide occurred in 2006 as well as two centennial floods in Oct. 2012 and June 2013. 


\subsection{Methodological approach}

The overall methodological approach combines participatory narrative scenarios with LULCC models in order to (i) produce future land cover maps, (ii) identify areas likely to experience LULCC in the future, and (ii) assess the subsequent evolution of landslide hazard in Cauterets. It consists in coconstructing, with stakeholders, fine-scale socio-economic scenarios, while developing a spatiallyexplicit local LULCC model. Narrative scenarios are built to provide relevant inputs to the LULCC model while the model itself is developed to represent and quantify the likely LULCC identified in the narrative scenarios. This fine-scale spatially-explicit approach (Houet et al. 2010; Houet et al. 2015; Houet et al. 2016b) allows identifying future LULCC likely to influence gravitational hazards.

Two foresight horizons (2040 and 2100) are considered. The former allows radical but realistic anthropogenic changes to be imagined while formulating relevant recommendations to decisionmaking timeframes. It is neither too close (pursuing trends only) nor too distant (preventing stakeholders from projecting so far into the future) in time. The latter captures the impacts of climate changes, which are expected to increase more sharply after 2050 (IPCC, 2014). In particular, peak oil, which is likely to have an impact on energy costs, and therefore, on the profitability of logging activities in forested areas, is assumed to occur in 2040 (Rozenberg et al. 2010).

\subsubsection{Downscaling scenarios: combining literature, participatory workshops and LULCC models}

The methodology for downscaling scenarios comprises six sequential steps: (1) pre-constructing national context scenarios, (2) downscaling national context scenarios to local scale, (3) story-telling of the narrative scenarios at local scale, (4) validating narratives and locating possible future land use changes, (5) simulating LULCC for each scenario, and (6) refining the narratives with quantitative and spatially explicit simulated outcomes.

Step 1: Pre-constructing national context scenarios.

The first step consisted of pre-constructing a set of national context scenarios describing the possible evolution of the social, economic, environmental, demographic and political conditions driving land use changes in mountain regions up to 2040. They formed the overall context that drew the geographical and socio-economic borders within which each of the local scale scenarios then had to fit.

A set of national and global driving forces and strong trends likely to influence future land uses in French mountain areas were first identified and characterized based on a literature review of existing prospective studies carried out at European and national levels (EEA 2007; Bourgau et al. 2008; Vert et Portet 2010; Vert et al. 2013) (Table 1). Driving forces are variables that are likely to vary across scenarios in the future, whether they stem from exogenous (e.g. volatility of agricultural prices, 
climate policies) or endogenous forces (e.g. urbanization, abandonment of farmland). Strong trends are variables whose evolution is considered as almost certain and that are occurring over all scenarios. They encompass global population growth, rising demand for agricultural products for food and feed uses and the impacts of climate change on mountain snow cover. Strong trends are used as contextual parameters to determine a set of pressures on the system. For instance, snow cover is expected to decrease by a factor of 2 to 5 from 2001 to 2030, compared to the reference period 1961-2000 (Rousselot et al. 2012; source: http://www.cnrm.meteo.fr/scampei/). As a result, the development of the ski resort is likely to be limited in absence of technological change.

As highlighted by Hérivaux (2015) and Petit et al. (2014), most prospective studies reflect a broad consensus on the range of likely futures of European societies. A cross analysis of existing foresight exercises in Europe and France allowed identifying four broad families of scenarios conventionally considered: globalization, regionalization, environmental preservation and sustainable food production. The national context scenarios were designed in line with these orientations and their underlying driving forces. For instance, the 'lettuce surprise U' scenario from EEA (2007) was used to define the policy and governance drivers such as decentralization of public policies in national context scenario 2 (Table 1). The approach was complemented by a series of face-to-face interviews with five French experts in the fields of agriculture, forestry and tourism in order to specify the likely evolution of some driving forces (e.g. the impact of technological change on ski resorts, the economic viability of forestry in the Pyrenees), given the peculiarities of mountain areas. Each scenario was then built as a consistent combination of strong trends and a set of key assumptions regarding each driving force. Such an approach relying on existing prospective studies and expert interviews to characterize driving forces and strong trends at national level is in line with methodologies used in previous research (Rinaudo et al. 2013; Graveline et al. 2014). At the end of step 1, four national context scenarios were constructed up to 2040.

Step 2: Downscaling national context scenarios to local scale.

The second step consisted of organizing a first workshop in order to debate and downscale the preconstructed national context scenarios with local stakeholders. A one-day workshop took place in Cauterets in November 2014 and gathered ten participants, including local policy-makers, state representatives, land managers and economic decision makers.

The workshop started with a retrospective analysis of the past evolution of the municipality based on historical LULCC maps from 1959 and 2010 (Fig.1). Past trends and dynamics in Cauterets regarding land cover changes, demography, tourism, agro-pastoral activities and forestry were presented and enriched with accurate explanations from local participants on both exogenous and endogenous drivers of change. This established a diagnosis of the situation of the municipality in 2010. The national context scenarios from 2010 to 2040 were then presented and debated. Participants were asked to react 
to the pre-constructed scenarios, complete the list of assumptions regarding the evolution of driving forces and re-construct local versions of the scenarios up to 2040 and 2100 as a combination of these new assumptions. For instance, the national context scenario 2 that depicts a quest for energy selfsufficiency was translated at local scale into the intensification of forestry production (Table 1).

The chain of events likely to occur from 2040 to 2100 was left open to participants, whose imagination was only constrained by two conditions common to all scenarios. First, the logical pathways between 2040 and 2100 had to match the trends described in each scenario from 2010 to 2040. This ensured that four local scale scenarios were built, each composed of two images (2040 and 2100), with two logical pathways (2010-2040 and 2040-2100). Second, the climate and energy contexts were predetermined, based respectively on the snow and temperature projections of Météo-France and the outputs of the IMACLIM-R model of CIRED describing possible changes in global energy prices through the $21^{\text {st }}$ century (Rozenberg et al. 2010). At the end of step 2, we had the material to build four local translations of the national context scenarios that were consistent with global scenarios while accounting for local specificities.

\section{Table 1 - approximately here -}

\section{Step 3: Story-telling of the narrative scenarios at local scale}

The third step consisted in rewriting the scenarios that emerged during the workshop in a narrative way. Particular attention was paid to clarifying the logical pathways linking the different elements identified as relevant by stakeholders for the 2010-2040 and 2040-2100 periods. At the end of step 3, four fine-scale narratives were built and described. These scenarios were sent to stakeholders two weeks before the second workshop organized in step 4 .

Step 4: Validating narratives and locating possible future land use changes.

Step 4 aimed to validate and provide a spatial characterization of the local scenarios in order to produce relevant data to be integrated in the LULCC model. A second one-day workshop took place in January 2015 and involved the same stakeholders as those that attended the first workshop. Participants were asked to debate the narrative scenarios' internal consistency and estimate their spatial impacts in terms of land use changes. Land cover maps were used to help participants to preidentify the likely zones of future land use changes and the time horizon for each. Such a participatory zoning technique based on both local stakeholders' verbal representations and scientists' comprehensive knowledge of the processes at play has been proved efficient as support to land management policies (Caron 1997; Caron and Cheylan 2005). Special attention was paid to future pastoral and forestry land uses as they have strong impacts on future land cover changes. Two types of maps were thus produced: (i) maps featuring the broad areas in which mountain estives might be abandoned, and (ii) maps featuring the broad areas in which forestry might occur. At the end of step 4, 
each scenario contained a revised narrative version of the local scale scenarios and two maps depicting the areas in which mountain land uses were likely to change from 2010 to 2040 and 2100 but without quantifying future LULCC.

\section{Step 5: Simulating LULCC for each scenario.}

Step 5 aimed to model the LULCC identified by stakeholders in order to ensure that they were consistent with the vegetation dynamics at play in Cauterets. The FORESCEM model used for mountain LULCC simulations was developed using the Dinamica-Ego platform (Soares-Filho and Coutinho Cerqueira 2002). It simulates LULCC at an annual time step and accounts for neighborhood interactions and feedbacks between some vegetation classes. To begin, it uses the two historical land use maps and land cover maps (10 x 10m resolution) from which it computes transition probabilities between land covers and land uses. A weight-of-evidence method is used to compute suitability maps to allocate future LULCC based on various spatially-explicit drivers (geology, aspect, elevation, slope, and distance to infrastructures, land uses and land covers). For each land use type (forestry, urbanization, agropastoral land use and abandonment considered as an absence of land use), land cover changes are defined either by transition probabilities or conversion rules aimed at reproducing vegetation dynamics (minimum duration, specific transitions from one land cover to another). Land use changes and conversion rules are driven by the narratives. Participatory zoning from step 4 is translated into GIS data to parameterize the land use changes in the model (details in supplementary material 1). For instance, pastoral land use changes (estive abandonment) define which estives are abandoned and when. When no abandonment is expected, land cover changes in the uplands are simulated according to trends estimated by the model. This may lead to land cover changes such as encroachment and reforestation which, in turn, may influence future land use changes (conversion from abandonment to forestry). Forestry land use changes are defined using an intermediate model (SYLVACCESS, Dupire et al. 2015, 2016) that delineates potential areas that can be logged according to logging practices. More precisely, it simulates all possible cableways used to remove cut trees, located within the zones pre-identified during step 4 . When scenarios expect to limit or stop a specific land use change, the transition probability is set to 0 by the modeler. The land demand is not predefined but computed from all simulated land cover and land use changes based on historical changes. Finally, the bio-physical impacts of global warming on reforestation are not taken into account because its influence on patterns and dynamics of mountain forests remains highly uncertain (Theurillat and Guisan, 2001) and even more when considering land use changes and anthropogenic disturbances (Galop et al. 2011; Batllori et al. 2010).

Step 6: Refining the narratives with quantitative and spatially explicit simulated outcomes.

Step 6 used the results of steps 4 and 5 to fine-tune and improve each narrative with quantitative outcomes regarding the location and the amount of simulated LULCC. At the end of step 6, four 
spatially explicit narratives had been constructed. Each was made of a scenario narrative, two finescale maps of future land cover up to 2040 and 2100 and a set of quantitative assessments of the associated amounts of LULCC.

\subsubsection{Assessing the future uncertainty of LULCC}

320

321

322

323

324

325

326

327

328

329

330

331

332

333

334

335

336

337

338

339

340

341

342

343

Areas at risk regarding gravitational hazards are identified based on the future uncertainty of LULCC assessed through a comparison of LULCC across scenarios. As described in Houet et al. (2015), the future uncertainty of land cover changes is defined as a multi-scenario ensemble assessment and computed using occurrences of specific land cover changes observed in all scenarios, similarly to Verburg et al. (2013). It delineates the largest spatial extent of future LULCC according to the envelope of possible futures. We assume that, in simulated scenarios, the more often a LULCC occurs at the same location, the more plausible and less uncertain it is (Wiek et al. 2013). In this paper, we focus on two vegetation dynamics that are most influential for gravitational hazards: reforestation and deforestation.

Reforestation is analyzed throughout the comparison of land cover maps for 2010 and 2100 to detect all transitions from any land cover to either dense forest or encroachment classes. Results from all scenarios are then combined into an occurrence map of reforestation and encroachment, transformed into relative probability (see Houet et al. 2015 for details). For deforestation, logging practices influence vegetation dynamics (growth - logging - regrowth over decades) and require a suitable procedure. Changes are extracted every decade from 2010 to 2100 and their occurrences are summed up in one map for each scenario, and then for all scenarios.

\subsubsection{Assessing landslide hazard over time using LULCC}

In order to demonstrate the interest of simulating future LULCC for decision makers and spatial planning policies, the simulated LULCC are used to assess changes in landslide activities in Cauterets up to 2100 . Only few studies assess the contribution of land use changes to changing risks (Promper et al. 2015), with a focus on the effect of land cover on slope stability (Reichenbach et al. 2014). These studies are based on statistical analyses that combine several parameters influencing landslide susceptibility. Here, landslide susceptibility is assessed using a spatially physical model.

LULCC are used as inputs to the ALICE (Assessment of Landslides Induced by Climatic Events) model (Baills et al. 2012). ALICE is a slope stability assessment tool that combines (i) a mechanical stability model accounting for some geotechnical parameters of the soil layers, (ii) an hydrogeological model that simulates the main water cycle mechanisms, and (iii) a vegetation module that has recently been added in order to account for the effects of vegetation shifts on mechanical soil properties (i.e. cohesion and overload). This spatialized mechanical model produces landslide hazard maps at various scales from the single slope to hundreds of square kilometers. Together, the mechanical stability model and the hydrogeological model allow integrating climate change scenarios. They are 
complemented by the vegetation module that accounts for the effects of LULCC on slope failures. In the module, vegetation shifts change the mechanical properties of soils, that in turn, affect the probability of reaching failure (Thomas and Pollen-Bankhead 2010; Genet et al. 2010; Kokutse et al. 2016). More precisely, the presence or absence of forest may have a counter-intuitive impact on slope stability as it can reinforce (i) the resistance to shear with an additional apparent cohesion of the soil due to roots or (ii) the instability due to the biomass additional weight.

Landslide hazards are assessed for the LULCC scenario that exhibits the least reforestation. The land cover maps for 2010 and 2100 are converted into additional cohesion and weights parameters and used as inputs to the ALICE model. In this application, rotational landslides with a length of $25 \mathrm{~m}$, and a depth between 1 and $3 \mathrm{~m}$ are considered. The model simulates landslide hazards for 2010 and 2100 and assesses the evolution of slope stability between 2010 and 2100 .

\section{Results}

Simulated land cover maps were produced annually for each scenario, and are illustrated for the 2040 and 2100 states in supplementary material 2. However, since these maps do not highlight the dynamics of change between two states, the evolution of the surface covered by each main land cover (in ha) is presented at a 10 years temporal resolution in Fig. 2.

\subsection{Spatially-explicit narratives}

\subsubsection{Scenario 1: Abandonment of the territory}

Market liberalization intensifies competition throughout the world. In Europe, the Common Agricultural Policy (CAP) disappears progressively from 2020 onwards. Increasing imports of lowcost agricultural products fosters the decline of mountain farming. In Cauterets, pastoral units that initially persisted thanks to transhumant herds coming from outer regions are eventually abandoned at a pace that depends on their accessibility, fodder potential and proximity to the valley. In 2040, farming is only maintained in a few highly productive grazing areas. In consequence, natural grasslands decrease in favor of dense forests that expand where both climate and soils are favorable to their expansion. By 2100, the effect of pastoral land abandonment is perceptible with an increase in the annual loss of natural grasslands in the uplands (5.6 ha/year) compared to the 2010-2040 period. The landscape has changed markedly with dense forests covering $33 \%$ of the territory in $1951,41 \%$ in 2010 , and $50 \%$ in 2100 .

\subsubsection{Scenario 2: Sheep and Woods}

In Europe, greater power is transferred to the regions, whose autonomy and influence increase. This regional downturn leads to decreasing trade which allows preserving French agriculture from global competition. In the Pyrenees Mountains, the CAP is reoriented so as to support local agriculture and renewable energy production. In Cauterets, uplands are grazed again and shrublands do not expand. 
Former agro-pastoral trails are remodeled for wood production and estives are reopened for agropastoralism on mountainsides. In parallel, the lack of investments in modernizing the equipment of the ski resort results in a decline in winter tourism. In 2040, Cauterets has lost its attractiveness for tourists. Compared to 2010, dense forests have lost 175 ha. By 2100, most of permanent inhabitants are gone. Logging activities induce significant landscape changes: mountainsides are regularly maintained and some previously abandoned pasture that evolved to shrublands and open forests are now reforested and exploited.

\subsubsection{Scenario 3: A renowned tourism resort}

With increasing globalization, the most vulnerable mountain areas are abandoned, while territories with higher economic potential are preserved for the purpose of their economic valorization. Due to its spectacular landscapes, Cauterets benefits from public support for the development of a high valueadded tourism. The use of snowmaking machines allows winter frequentation to remain stable while summer frequentation increases with the diversification of outdoor activities. The municipality invests in logistical and financial support to maintain natural areas. However, forestry remains costly and the downward trend of agro-pastoralism continues. Only grazing areas that are located close to tourist areas are artificially maintained in order to sustain a bucolic pastoral landscape (e.g. sheepfolds, flowery meadows). Some intermediate areas are reopened in order to prevent landscapes from closing. Elsewhere, landscape dynamics follow similar trends to scenario 1. In 2040, large areas of natural grassland have turned into shrublands or open/dense forests. Dense forest areas increase by 5.2 ha/year from 2040 to 2100 . By $2100,49 \%$ of the study area is covered by dense forests, which is perceived as an attractive factor since Cauterets has become a socially selective tourist destination.

\subsubsection{Scenario 4: Green Town}

Increasing environmental awareness modifies consumption habits and lifestyles. Prices of fossil fuels and imports increase while investments in renewable energy, local agriculture and green technologies are boosted in Europe. In Cauterets, the wider use of telecommunications and teleworking reduces rural exodus of city dwellers. The use of grazing areas continues but the decrease in livestock in the valley reduces grazing pressure in the mountains. This results in shrub invasion and encroachment of the least productive estives. Meanwhile, wood production increases. By 2040, Cauterets is a multifunctional area providing a pleasant living environment and good-quality services to its population. Compared to 2010, landscapes have significantly changed: they lost $11 \%$ of grasslands and $3.3 \%$ of dense forests. In the following decades, tourism decreases progressively with rising travel costs and the shrinking of the ski area. A small agro-pastoral activity remains but forest expands significantly across the whole area with reforestation trends comparable to what they were before 2010. In $2100,49 \%$ of the study area is covered by dense forest, similarly to scenarios 1 and 3. 


\subsection{Comparison of land cover changes and identification of areas at stake}

420 As a first result, a slower pace of reforestation and encroachment is observed in all scenarios compared to the 1951-2010 period. This difference in transitional rates may be explained by the productivity gains and subsequent massive rural exodus that French mountain agriculture experienced during the second half of the 20th century which is out of proportion with any future change that might occur. Reforestation and encroachment occurring up to the present day have concerned mountainsides. From 2010 to 2100 , net changes in dense forests do not significantly differ from one scenario to another, except for scenario 2 (Fig. 2b). Although scenarios 1, 3 and 4 exhibit strong differences in terms of land uses and social values, they show similar trends in land cover changes. Scenario 2, which expects breakdowns regarding land use changes, limits the major trend of reforestation observed in the Pyrenees although it does not stop it totally. Shrublands in the uplands show similar results (Fig. 2a): scenarios 1, 3 and 4 exhibit identical trends even though pastoral land uses are maintained in some estives for scenarios 3 and 4 .

\section{Figure 2 - Approximately here}

Conversely, landscape changes exhibit subtle differences in terms of location (Fig 3). The map of future uncertainty on deforestation provides an overview of the probability of areas becoming deforested in the future, according to future land management and land use changes described in the scenarios (Fig 3a). As scenario 1 does not expect any deforestation, there is no pixel with a probability of 1 . Forests having the highest probability of being deforested are located near built-up areas, which is of interest to gravitational hazards. As for reforestation and encroachment, the map of their future uncertainty (Fig 3b) provides interesting insights into the areas at stake, since (i) most areas with a high probability of change are located in remote places and are encroached in 2010, and (ii) areas with a low probability (i.e. that may be forested in the distant future) are not necessarily currently shrublands. The estives of Cirques du Lys, Lisey and Gourey appear to be highly susceptible to encroachment and reforestation although the first two are easily accessible (Fig 3a). Finally, considering all scenarios, Figure $3 \mathrm{c}$ identifies the largest envelope and the relative probability of future forest cover changes, likely to influence gravitational hazards.

\section{Figure 3-Approximately here}

\subsection{Landslide hazard assessment}

Because it exhibits the most deforestation, scenario 2 was selected to assess the influence of the evolution of the vegetation cover on landslide activities up to 2100. Results that are presented in Fig. 4 focus on an area of Cauterets that has been particularly at risk in the past. They show an increase in the probability of landslide occurrence in the absence of forests and an increase in slope stability in the presence of forests (Fig 4a). From 2010 to 2100, results indicate that reforestation will tend to increase 
the stability of the slopes, whereas the stability will be dropping in deforested areas (Fig 4b). This demonstrates the significant influence of land covers in stability computations. Such results points out that for spatialized analysis of landslide hazard, considering spatially-explicit LULCC undoubtedly improves the accuracy of the landslide hazard computations.

\section{Figure 4-Approximately here}

\section{Discussion}

The approach developed to construct the narratives at local scale relied on pre-constructed national scenarios that described the overall socio-economic context with which each narrative had to be consistent. This guided stakeholders towards likely futures that were in line with the scenarios used to feed public policy developments at the national and European levels. Since workshop participants had never participated in a foresight exercise before, the national context scenarios also played a key role in helping them project into the future. In return, they limited the range of possible futures that could be considered during the workshops. However, the timeframe allotted to the construction of the scenarios within our research project (only 4 months) did not allow the past evolution of each of the driving forces to be thoroughly investigated and then contrasted hypotheses of their future evolution to be constructed, as recommended by Godet and Roubelat (1996). Given this constraint, our approach constitutes a time-efficient alternative for co-constructing useful prospective scenarios with local stakeholders.

Involving local stakeholders in the development of scenarios allowed exploring breakdowns and unexpected changes. It benefited to both scientists, who confronted their theoretical knowledge with ground realities, and local decision makers, whose participation in a formalized foresight exercise helped intellectualize and anticipate changes in a longer time horizon than the short term constraints they are used to handling, as pinpointed by Rinaudo et al. (2013) and van Vliet et al. (2010). The approach also confirmed that participation enabled scientifically grounding the local knowledge of participants while building a shared expertise among stakeholders. It brought together stakeholders with various opinions that now share a common vision of the future of their territory. In the future, this common understanding is likely to facilitate the establishment of effective risk management strategies by providing sound foundations for the decision process.

The approach contributed to the design of the LULCC model architecture by decoupling land use changes driven by the narratives, from land cover changes driven by vegetation dynamics observed between 1959 and 2010 and further simulated in the model. Thus, the parameters of the model were fine-tuned in light of up-to-date local information, thereby ensuring its calibration. In turn, the types of data required by the model fed the zoning technique used to spatialize land use changes associated with each scenario. Stakeholders were able to characterize the occurrence of the land use changes 
resulting from the scenarios in time and space, given local peculiarities. Conventional LULCC models would not have been able to define such changes by themselves when calibrated using historical changes. More generally, the consultation of stakeholders provided a solution to overcome the lack of accurate data at local scale, thus avoiding the 'black-box' effect that explains the reluctance of some decision-makers to assimilate the results of models whose operation they do not fully understand. In regard to modelling issues, as highlighted by Verburg et al. (2016), the FORESCEM model tackles the challenge of accounting for iterative feedbacks between land cover changes and land use changes at a fine scale. Thus, a particular attention has been paid concomitantly to the impacts of pastoral (abandonment of summer pastures) and forestry (emergence of logging) land use changes on land cover changes and the impacts of some trends in land cover changes (natural reforestation) on land use changes. The ability of LULCC models to represent feedbacks is crucial for simulating co-constructed scenarios through a dynamic process.

Results of the LULCC model show a common trend across all scenarios. Natural grasslands exhibit a major declining trend in the uplands, in favor of encroachment and reforestation. Future LULCC, taken independently, may pursue the forest transition theory of Mather (1992) up to the beginning of the $22^{\text {nd }}$ century at least. Even if these trends are similar across all scenarios between 2010 and 2100 , they exhibit subtle differences in terms of quantity and location over time. Results strongly depend on the date considered. For instance, the four scenarios show similar surfaces of forests in 2090 but trends diverge over the following decade, leading to different surfaces in 2100 (Fig 2). Thus, it is of great importance to consider the landscape dynamics rather than only focusing on changes between two LULC maps. Moreover, while diverging global assumptions would be expected to have diverging impacts on future LULCC, they show similar outcomes in Cauterets over the next century (e.g. the economic downturn in scenario 2 and the boost of the green economy in scenario 4 lead to similar landscape configurations for some specific dates). In the same way, different local economic developments have similar effects on landscape changes (e.g. tourism development varies significantly in scenarios 1 and 4 while reforestation trends are rather similar). Although this analysis can be balanced by the spatial and temporal resolutions considered, these findings underline an important insight: global scenarios may not necessarily result in similar effects locally over distinct valleys or mountains. Local specificities are likely to influence the translation of global / national contexts locally, leading either to diverging or converging landscape dynamics. This questions the relevance of large scale scenario-based studies to inform local decision-making processes.

From a more global point of view, assessing the future uncertainty of LULCC enabled identifying plausible areas for reforestation or deforestation across scenarios. In Cauterets, these areas differ greatly, with reforestation going mainly beyond the past tree line and deforestation occurring on mountainsides. Overall, some areas are particularly likely to encounter land cover changes (deforestation, reforestation and encroachment) no matter which scenarios are considered. 


\section{Conclusion}

524 The present study investigates the contribution of coupling participatory approaches in downscaling 525 socio-economic prospective scenarios with LULCC modelling in order to assess gravitational risks in 526 mountain areas, with an application to a case study located in the French Pyrenees. It develops a six 527 step methodology for co-designing with stakeholders fine-scale spatially-explicit scenarios up to 2040 and 2100. The main interest of such a combination is to allow localizing and quantifying future

529

530

531

532

533

534

535

536

537 LULCC in light of data stemming from local stakeholders and to account for the uncertainties associated with future socio-economic changes.

Results show that national context scenarios are not strong drivers of land-use changes at local scales, stressing the need to account for their local declination. Participatory approaches allow fulfilling this need by capturing local adaptations of communities to global contexts. As for the model, it enables to account for interactions and feedbacks between LULCC that may explain some specific local landscape changes. These findings highlight the importance of considering landscape dynamics (yearly or over decades) instead of one or two dates in the future to analyze and compare spatiallyexplicit scenarios.

The information provided by the simulated LULCC also proved to be of particular interest for natural hazard assessments. Our approach allowed identifying changes in the vegetation cover that will significantly affect landslide hazards in upcoming decades. Such results confirm the added-value of accounting for future LULCC to improve the accuracy of gravitational risk assessments in mountain areas. They also highlight the relevance for policy-makers of scenario-based LULCC modelling that supports decision-making under uncertainty.

The next step of the methodology should be to further extend the consultation process so as to construct relevant multi-risk reduction strategies with local stakeholders in order to reduce the vulnerability and foster the resilience of societies to climate-driven natural hazards.

\section{Acknowledgments}

This study was part of the SAMCO project (Society Adaptation for coping with Mountain risks in a global change Context) funded by the French National Research Agency (ANR 12 SENV-0004 SAMCO). We would like to thank the Pyrenees National Park for providing historical GIS data, and the reviewers for their constructive comments on the earlier draft.

\section{References}

Alcamo J (2008) The SAS approach: combining qualitative and quantitative knowledge in environmental scenarios, In: Alcamo J (ed), Environmental Futures: the Practice of Environmental Scenario Analysis, Elsevier, Amsterdam, pp 123-150 
Baills A, Vandromme R, Desramaut N, Sedan O, Grandjean G (2012) Changing patterns in climate-driven landslide hazard: an alpine test site. The Second World Landslides Forum Oct 2011, Springer-Verlag, Rome, pp 4

Batllori E, Camarero J J, Gutierrez E (2010) Current regeneration patterns at the tree line in the Pyrenees indicate similar recruitment processes irrespective of the past disturbance regime. Journal of Biogeography 37:1938-1950. doi:10.1111/j.1365-2699.2010.02348.x

Borsdorf A, Stötter J, Grabherr G, Bender O, Marchant C, Sánchez R (2015) Impacts and risks of global change. In: Grover V I, Borsdorf A, Breuste J, C.Tiwari P, Witkowski Frangetto F (Eds) Impact of global changes on mountains. Responses and adaptation, Boca Raton, CRC Press, pp 33-76

Bourgau J M, Bertin M, Lerat J F, Monnot J G, Morin G A, Poss Y (2008) La forêt française en 2050-2100, Essai de prospective, Conseil Général de l'Agriculture, de l'Alimentation et des Espaces Ruraux, http://agriculture.gouv.fr/telecharger/69218?token=dd68fdb058b8ed13ec1d77cf75b16fd1. Accessed 28 February 2017

Brang P, Schönenberger W, Ott E, Gardner B (2001) Forests as Protection from Natural Hazards. In: Evans J (ed) The forests handbook. Vol. 2: Applying forest science for sustainable management Blackwell Science, Oxford, pp 53-81

Brown D G, Page S, Riolo R, Zellner M, Rand W (2005) Path dependence and the validation of agent-based models of land use. International Journal of Geographical Information Science 19(2):153-174. doi: $10.1080 / 13658810410001713399$

Caron P (1997) Le zonage régional à dires d'acteurs. Connaître, représenter, planifier, agir, une méthodologie expérimentée dans le Nordeste du Brésil. Actes du Séminaire dynamiques agraires et construction sociale du territoire 26-28/04/1999, Montpellier http://www.supagro.fr/documentation/doc_irc/Publications/etudes_travaux18/052\%20connaitre\%20represe nter.pdf Accessed 28 February 2017

Caron P, Cheylan J P (2005) Donner sens à l'information géographique pour accompagner les projets de territoire : cartes et représentations spatiales comme supports d'itinéraires croisés, Geocarrefour, 80(2):111122

Carter TR, La Rovere EL, Jones RN, Leemans R, Mearns LO, Nakicenovic N, Pittock AB, Semenov SM, Skea J (2001) Developing and applying scenarios. In: McCarthy JJ, Canziani OF, Leary NA, Docken DJ, White KS (eds) Climate change 2001: Impacts, adaptation, and vulnerability. Contribution of working group II to the third assessment report of the intergovernmental panel on climate change. Cambridge University Press, Cambridge and New York, pp 145-190

Dupire S, Bourrier F, Berger F (2016) Predicting load path and tensile forces during cable yarding operations on steep terrain. Journal of Forest Research 21(1):1-14. doi: 10.1007/s10310-015-0503-4

Dupire S, Bourrier F, Monnet J M, Berger F (2015) Sylvaccess : un modèle pour cartographier automatiquement l'accessibilité des forêts. Revue forestière française 2:16. doi: 10.4267/2042/57902 
EEA (2007) Land-use scenarios for Europe: qualitative and quantitative analysis on a European scale, PRELUDE, European Environment Agency Technical Report No 9/2007 http://www.eea.europa.eu/publications/technical_report_2007_9/at_download/file Accessed 28 February 2017

Forbes K, Broadhead J (2013) Forests and landslides. The role of trees and forests in the prevention of landslides and rehabilitation of landslide-affected areas in Asia. Second edition. Food and Agriculture Organization of the United Nations Regional Office for Asia and the Pacific Bangkok.

Fuchs R, Verburg PH, Clevers J, Herold M (2015a) The potential of old maps and encyclopedias for reconstructing historic European land cover/use change. Applied Geography 59:43-55. doi: 10.1016/j.apgeog.2015.02.013

Fuchs R, Herold M, Clevers J, Verburg PH (2015b) Net change versus gross change in historic land use reconstructions. Change Biology 21(1):299-313. doi: 10.1111/gcb.12714

Galop D, Houet T, Mazier F, Leroux G, Rius D (2011) Grazing activities and biodiversity history in the Pyrénées - the use of paleoecology and historical ecology to provide new insights on high-altitude ecosystems in the framework of a Human-Environment Observatory, PAGES news, 19(2):53-56

Genet M, Stokes A, Fourcaud T, Norris JE (2010) The Influence of Plant Diversity on Slope Stability in a Moist Evergreen Deciduous Forest. Ecological Engineering 36(3):265-75. doi: 10.1016/j.ecoleng.2009.05.018.

Gibon A, Sheeren D, Monteil C, Ladet S, Balent G (2010) Modelling and simulating change in reforesting mountain landscapes using a social-ecological framework, Landscape Ecology 25(2):267-285. doi: $10.1007 / \mathrm{s} 10980-009-9438-5$

Godet M, Roubelat F (1996) Creating the future: the use and misuse of scenarios. Long Range Planning 29(2):164-171. doi: 10.1016/0024-6301(96)00004-0

Graveline N, Loubier S, Gleyses G, Rinaudo J D (2012) Impact of farming on water resources: assessing uncertainty with Monte Carlo simulations in a global change context. Agricultural Systems 108:29-41. doi : 10.1016/j.agsy.2012.01.002

Graveline N, Auney B, Fusillier J L, Rinaudo J D (2014) Coping with urban and agriculture water demand uncertainty in water management plan design: the interest of participatory scenario analysis, Water Resource Management 28:3075-3093. doi: 10.1007/s11269-014-0656-5

Hérivaux C (2015) Bilan des prospectives Agriculture-Eau-Territoires en France: scénarios, facteurs de changement et utilisation pour la mise en œuvre de la DCE. BRGM/RP-63084-FR

Houet T, Loveland TR, Hubert-Moy L, Napton D, Gaucherel C, Barnes C (2010) Exploring subtle land use and land cover changes: a framework based on future landscape studies, Landscape Ecology 25(2):249-266 doi: 10.1007/s10980-009-9362-8 
Houet T, Schaller N, Castets M, Gaucherel C (2014) Improving the simulation of fine scale landscape changes coupling top-down and bottom-up land use and cover changes rules. International Journal of Geographical Science 28(9):1848-1876. doi: 10.1080/13658816.2014.900775

Houet T (2015) Usages de modèles spatiaux pour la prospective, Revue Internationale de Géomatique 25(1):123143. doi: $10.3166 /$ rig.25.123-143

Houet T, Vacquié L, Sheeren D (2015) Evaluating the spatial uncertainty of future land abandonment in a mountainous valley (Vicdessos, Pyrenees - France): insights from model parameterization and experiments. The Journal of Mountain Science 12(5):1095-1112. doi: 10.1007/s11629-014-3404-7

Houet T, Aguejdad R, Doukari O, Battaia G, Clarke K (2016a) Description and validation of a 'non pathdependent' model for projecting contrasting urban growth futures, Cybergeo, 759, http://cybergeo.revues.org/27397 accessed 28 February 2017

Houet T, Marchadier C, Bretagne G, Moine MP, Aguejdad R, Viguié V, Bonhomme M, Lemonsu A, Avner P, Hidalgo J, Masson V (2016b) Combining narratives and modeling approaches to simulate fine scale and long-term urban growth scenarios for climate adaptation. Environmental Modelling and Software 86:1-13. doi: 10.1016/j.envsoft.2016.09.010

IPCC (2012) Summary for policymakers. In: Field C B, Barros V R, Stocker T F, Qin D, Dokken D J, Ebi K L (eds), Managing the risks of extreme events and disasters to advance climate change adaptation. A special report of working groups I and II of the Intergovernmental Panel on Climate Change. Cambridge and New York USA: Cambridge University Press. pp 1-19 https://www.ipcc.ch/pdf/specialreports/srex/SREX_FD_SPM_final.pdf accessed 24 april 2017

IPCC (2014) Summary for policymakers. In: Field C B, Barros V R, Dokken D J, Mach K J, Mastrandrea M D, Bilir T E, Chatterjee M, Ebi K L, Estrada Y O, Genova R C, Girma B, Kissel E S, Levy A N, MacCracken S, Mastrandrea P R and White L L (eds.) Climate Change 2014: Impacts, Adaptation, and Vulnerability. Summaries, Frequently Asked Questions, and Cross-Chapter Boxes. A Contribution of Working Group II to the Fifth Assessment Report of the Intergovernmental Panel on Climate Change: World Meteorological Organization, Geneva, Switzerland, pp. 1-32. https://www.ipcc.ch/pdf/assessmentreport/ar5/wg2/WGIIAR5-IntegrationBrochure_FINAL.pdf accessed 24 april 2017

Katz RW, Brown BG (1992) Extreme events in a changing climate: Variability is more important than averages, Climatic Change 21:289-302. doi: 10.1007/BF00139728

Kohler T, Wehrli A, Jurek M (2014) Mountains and climate change: A global concern. Sustainable Mountain Development Series. Bern, Centre for Development and Environment (CDE), Swiss Agency for Development and Cooperation (SDC) and Geographica Bernensia

Kok K (2009) The potential of Fuzzy Cognitive Maps for semi-quantitative scenario development, with an example from Brazil. Global Environmental Change 19:122-133. doi: 10.1016/j.gloenvcha.2008.08.003 
Kokutse NK, Temgoua AGT, Kavazović Z (2016) Slope Stability and Vegetation: Conceptual and Numerical Investigation of Mechanical Effects. Ecological Engineering 86:146-53. doi: 10.1016/j.ecoleng.2015.11.005

Kolb M, Mas J F, Galicia L (2013) Evaluating drivers and transition potential models in a complex landscape in southern Mexico. International Journal of Geographical Information Science. 27(9):1804-1827. doi:10.1080/13658816.2013.770517

Kozak J, Estreguil C, Troll M (2007) Forest cover changes in the northern Carpathians in the 20th century: a slow transition, Journal of Land Use Science 2:127-146. doi:10.1080/17474230701218244

Liu J, Hull V, Batistella M, DeFries R, Dietz T, Fu F, Hertel T, Izaurralde C, Lambin E, Li S, Martinelli L, McConnell W, Moran E, Naylor R, Ouyang Z, Polenske K, Reenberg A, de Miranda G, Simmons C, Verburg PH, Vitousek P, Zhang F, Zhu C (2013) Framing sustainability in a telecoupled world. Ecology and Society, 18(2):26. doi: 10.5751/ES-05873-180226

Malek Z, Boerboom L (2015) Participatory Scenario Development to Address Potential Impacts of Land Use Change: An Example from the Italian Alps, Mountain Research and Development 35(2):126-138. doi: 10.1659/MRDJOURNAL-D-14-00082.S1

Mallampalli VR, Mavrommati G, Thompson J, Duveneck M, Meyer S, Ligmann-Zielinska A, Gottschalk Druschke C, Hychka K, Kenney M A, Kok K, Borsuk ME (2016) Methods for translating narrative scenarios into quantitative assessments of land use change, Environmental Modelling and Software 82:720. doi: 10.1016/j.envsoft.2016.04.011

Mas JF, Kolb M, Paegelow M, Camacho Olmedo MT, Houet T (2014) Modeling Land use / cover changes: a comparison of conceptual approaches and softwares. Environmental Modelling and Software 51:94-111. doi: 10.1016/j.envsoft.2013.09.010

Mather A S (1992) The forest transition, Area, 24 (4), 367-379

Moos C, Bebi P, Graf F, Mattli J, Rickli C, Schwarz M (2016) How does forest structure affect root reinforcement and susceptibility to shallow landslides? Earth Surface Processes and Landforms 41:951960. doi: 10.1002/esp.3887

Müller D, Sun Z, Vongvisouk T, Pflugmacher D, Xu J, Mertz O (2014) Regime shifts limit the predictability of land-system change. Global Environmental Change 28:75-83. doi:10.1016/j.gloenvcha.2014.06.003

Olesen JO, Bindi M (2002), Consequences of climate change for European agricultural productivity, land use and policy, European Journal of Agronomy 16(4):239-262. doi:10.1016/S1161-0301(02)00004-7

Papathoma-Köhle M, Kappes M, Keiler M, Glade T (2011) Physical vulnerability assessment for alpine hazards:state of the art and future needs, Natural Hazards, 58:645-680. doi:10.1007/s11069-010-9632-4

Petit M, El Hadad-Gauthier F (2014) Review of prospective studies for mediterranean agriculture: implications for

agricultural

research. 

http://www.iamm.ciheam.org/ress_doc/opac_css/doc_num.php?explnum_id=14385 Accessed 28 February 2017

Pérez-Soba M, Paterson J, Metzger M (2015). Visions of future land use in Europe: stakeholder visions for 2040. VOLANTE project report, Alterra Wageningen UR http://www.volante-project.eu/docs/visions.pdf Accessed 28 February 2017

Price B, Kienast F, Seidl I, Ginzler C, Verburg P H, Bolliger J (2015) Future landscapes of Switzerland: risk areas for urbanisation and land abandonment. Applied Geography 57:32-41. doi: 10.1016/j.apgeog.2014.12.009

Promper C, Puissant A, Malet JP, Glade T (2014) Analysis of land cover changes in the past and the future as contribution to landslide risk scenarios, Applied Geography 53:11-19. doi: 10.1016/j.apgeog.2014.05.020

Promper C, Gassner C, Glade T (2015) Spatiotemporal patterns of landslide exposure - a step within future landslide risk analysis on a regional scale applied in Waidhofen/Ybbs Austria. International Journal of Disaster Risk Reduction 12:25-33. doi: 10.1016/j.ijdrr.2014.11.003

Reichenbach P, Busca C, Mondini A C, and Rossi M (2014) The Influence of Land Use Change on Landslide Susceptibility Zonation: The Briga Catchment Test Site (Messina, Italy), Environmental Management 54(6):1372-1384. doi: 10.1007/s00267-014-0357-0

Rey Benayas JM, Martins A, Nicolau JM et al. (2007) Abandonment of agricultural land. An overview of drivers $\begin{array}{lllll}\text { and } & \text { consequences. } & \text { CAB } & \text { Reviews: } & \text { Persp. }\end{array}$ http://www3.uah.es/josemrey/Reprints/ReyBenayasetal_Landabandonment_Perspectives_07.pdf Accessed 28 February 2017

Rinaudo JD, Maton L, Matona L, Terrason I, Chazot S, Richard-Ferroudji A, Caballeroa Y (2013) Combining scenario workshops with modelling to assess future irrigation water demand, Agricultural Water Management 130:103-112. doi:10.1016/j.agwat.2013.08.016

Rousselot M, Durand Y, Giraud G, Mérindol L, Dombrowski-Etchevers I, Déqué M, Castebrunet H (2012) Statistical adaptation of ALADIN RCM outputs over the French Alps - application to future climate and snow cover, The Cryosphere 6:785-805. doi:10.5194/tc-6-785-2012, 2012

Rounsevell MDA, Reginster I, Arajo MB, Carter TR, Dendoncker N, Ewert F, House J I, Kankaanpää S, Leemans R, Metzger MJ, Schmit C, Smith P, Tuck G (2006) A coherent set of future land use change scenarios for Europe. Agriculture, Ecosystems \& Environment 114:57-68. doi: 10.1016/j.agee.2005.11.027

Rozenberg J, Hallegatte S, Vogt-Schilb A, Sassi O, Guivarch C, Waisman H, Hourcade JC (2010) Climate policies as a hedge against the uncertainty on future oil supply, Climatic Change 101(3-4):663-668. doi: 10.1007/s10584-010-9868-8

Soares-Filho BS, Coutinho Cerqueira G (2002) DINAMICA - a stochastic cellular automata model designed to simulate the landscape dynamics in an Amazonian colonization frontier. Ecological Modelling 154:217235. doi: 10.1016/S0304-3800(02)00059-5 
Stürck J, Schulp CJE, Verburg PH (2015a) Spatio-temporal dynamics of regulating ecosystem services in Europe - The role of past and future land use change, Applied Geography 63:121-135. doi: 10.1016/j.apgeog.2015.06.009

Stürck J, Levers C, van der Zanden E H, Schulp C J E, Verkerk P J, Kuemmerle T, Helming J, Lotze-Campen H, Tabeau A, Popp A, Schrammeijer E, Verburg PH (2015b) Simulating and delineating future land change trajectories across Europe, Regional Environmental Change 1-17, doi: 10.1007/s10113-015-0876-0

Theurillat JP, Guisan A (2001) Potential Impact of Climate Change on Vegetation in the European Alps: A Review, Climatic Change 50: 77-109. doi: 10.1023/A:1010632015572

Thomas R E, Pollen-Bankhead N (2010) Modeling Root-Reinforcement with a Fiber-Bundle Model and Monte Carlo Simulation. Ecological Engineering 36(1):47-61. doi: 10.1016/j.ecoleng.2009.09.008.

Vacquié L, Houet T, Sohl T, Reeker R, Sayler K (2015) Developing scenarios to project LULC changes in the Pyrenees (France): a model-based approach to assess land abandonment and reforestation dynamics. The Journal of Mountain Science 12(4):905-920. doi: 10.1007/s11629-014-3405-6

van Vliet M, Kok K, Veldkamp T (2010) Linking stakeholders and modellers in scenario studies: The use of Fuzzy Cognitive Maps as a communication and learning tool, Futures 42(1):1-14. doi: 10.1016/j.futures.2009.08.005

van Vuuren D P, Kok M T J, Girod B, Lucas P L, de Vries B (2014) Scenarios in Global Environmental Assessments: Key characteristics and lessons for future use, Global Environmental Change 22(4):884-895. doi: 10.1016/j.gloenvcha.2012.06.001

Verburg PH, Van Berkel D, Van Doorn A, Van Eupen E, Van den Heiligenberg H (2010) Trajectories of land use change in Europe: a model-based exploration of rural futures. Landscape Ecology (25)2:217-232. doi: $10.1007 /$ s10980-009-9347-7

Verburg PH, Tabeau A, Hatna E (2013) Assessing spatial uncertainties of land allocation using a scenario approach and sensitivity analysis: A study for land use in Europe. Jounal of Environmental Management S127-S132. doi: 10.1016/j.jenvman.2012.08.038

Verburg PH, Dearing J A, Dyke J G, van der Leeuw S, Seitzinger S, Steffen W, Syvitski J (2016) Methods and approaches to modelling the Anthropocene. Global Environmental Change 82:7-20. doi: 10.1016/j.gloenvcha.2015.08.007

Verkerk PJ, Lindner M, Pérez-Soba M, Paterson JS, Helming J, Verburg PH, Kuemmerle T, Lotze-Campen H, Moiseyev A, Müller D, Popp A, Schulp CJE, Stürck J, Tabeau A, Wolfslehner B, van der Zanden EH (2016) Identifying pathways to visions of future land use in Europe, Regional Environmental Change 1-14, doi: 10.1007/s10113-016-1055-7

Vert J, Portet F (2010) Prospective Agriculture Énergie 2030. L'agriculture face aux défis énergétiques, Centre d'études et de prospective, Ministère de l'Agriculture, de l'Alimentation, de la Pêche, de la ruralité et de l'Aménagement territoire. 

February 2017

Vert J, Schaller N, Villien C (2013) Agriculture Forêt Climat: vers des stratégies d'adaptation, Centre d'études et de prospective, Ministère de l'Agriculture, de l'Agroalimentaire et de la Forêt. http://agriculture.gouv.fr/telecharger/54567?token=1923b22f9b4b2aa312d7256ca7d151fb Accessed 28 February 2017

Voinov A, Bousquet F (2010) Modelling with stakeholders, Environmental Modelling and Software 25(11):1268-1281, doi: 10.1016/j.envsoft.2010.03.007

Wiek A, Withycombe Keeler L, Schweizer V, Lang, D J (2013) Plausibility indications in future scenarios, International Journal of Foresight and Innovation Policy, 9(2/3/4):133-147. doi: 10.1504/IJFIP.2013.058611

\section{Figure captions}

Fig.1: Presentation of the study site: (a) relief, land uses and land covers in (b) 1959, (c) 2010 and (d) their changes, and (e) the main administrative estives

Fig. 2: Future land use and land cover changes (in hectares) for (a) each main land cover and (b) the dense forests (coniferous + Decidous/Mixed forests) for the four scenarios.

Fig. 3 Future uncertainty maps - probability ranges from 0 to 1 - for (a) the deforestation, (b) the reforestation and encroachment. (c) illustrates the difference map between (a) and (b) underlying that few areas are concerned by both deforestation and reforestation dynamics in the future. Red lines illustrate roads and grey lines show boundaries of estives numbered in (a) (1 Coutres, 2 Estibe, 3 Gourey, 4 Cirque du Lys, 5 ClosCayan, 6 Vallée de Gaube, 7 Vallée de Lutour, 8 Lisey, 9 Le col de Riou, 10 Viscos)

Fig. 4: Modelling the influence of vegetation on the Factor of Safety (FoS) of shallow rotational landslides susceptibility. (a) Differences between the FoS probabilities without and with the vegetation in 2010 illustrating the positive influence of the vegetation to limit landslides. (b) Differences between the Fos probabilities using the land cover maps in 2010 and in 2100 according to Sc2 illustrating that land use and land cover changes may have subtle local impact on landslides.

Table 1: Main characteristics of the four national and local socio-economic scenarios up to 2040 